\title{
Students' Critical Thinking: A Study on Science Teaching Material Based on the Scientific Approach
}

\author{
Lisa Ariyanti Pohan",*, Julia Maulina', Tuti Hardianti ${ }^{2}$ \\ ${ }^{1}$ Department of Chemistry Education, Universitas Islam Sumatera Utara, Medan, Indonesia \\ ${ }^{2}$ Department of Physic Education, Universitas Islam Sumatera Utara, Indonesia
}

Received October 9, 2020; Revised November 20, 2020; Accepted December 13, 2020

\begin{abstract}
Cite This Paper in the following Citation Styles
(a): [1] Lisa Ariyanti Pohan, Julia Maulina, Tuti Hardianti, "Students' Critical Thinking: A Study on Science Teaching Material Based on the Scientific Approach," Universal Journal of Educational Research, Vol. 8, No. 12B, pp. 8129-8136 2020. DOI: 10.13189/ujer.2020.082615.
\end{abstract}

(b): Lisa Ariyanti Pohan, Julia Maulina, Tuti Hardianti (2020). Students' Critical Thinking: A Study on Science Teaching Material Based on the Scientific Approach. Universal Journal of Educational Research, 8(12B), 8129-8136. DOI: 10.13189/ujer.2020.082615.

Copyright $\odot 2020$ by authors, all rights reserved. Authors agree that this article remains permanently open access under the terms of the Creative Commons Attribution License 4.0 International License

\begin{abstract}
The teaching materials in this study were developed using a scientific approach in terms of the structure of their preparation and development. They were developed to direct students to active learning and improve their critical thinking. Critical thinking skills are highly needed to solve complex problems in various situations, including those that arise in the communication technology industry era. This study was designed as a research and development. The subjects of the study were 45 students of 7th grade, and the object was the students' critical thinking skills through the application of teaching materials based on a scientific approach. Teaching materials development was carried out through 1) needs analysis; 2) product design includes the formulation of learning objectives, writing teaching materials following the scientific approach, and deepening the content of the materials; 3 ) initial product assessment stage, and 4) application of teaching materials. The data obtained were analyzed with descriptive and inferential statistics using an independent sample t-test. The results show that the teaching materials developed were feasible to use with a score of 4.28 in the very good category. Student responses to teaching materials based on a scientific approach were in the high response category. Based on testing with the independent sample t-test, the P-value obtained was $0.0437<0.05$. Therefore, it can be concluded that the use of scientific approach-based teaching materials has an effect on improving students' critical thinking skills.
\end{abstract}

Keywords Development, Scientific Teaching Material, effectiveness, Critical Thinking

\section{Introduction}

Science is one of the basic knowledge studied at the elementary, secondary to a higher level of education. One of the main goals of studying science is to develop students' critical thinking. Critical thinking is needed in various disciplines and is useful for the profession that will be pursued in the future [1]. Critical thinking is included as one of the most important skills in 21 st-century learning, as it is one of the capitals of success in the workplace [2].

Critical thinking is an active intellectual process that is skillfully formulating concepts, applying, analyzing, synthesizing, and evaluating the information collected. This whole process can be obtained from observation, experience, reflection, reasoning, and communication [3]. Critical thinking is a thought process that is related to our ability to think rationally-being able to think to solve problems by using reasons that come from knowledge in the form of facts and information stored in the thought. It is also a cognitive activity related to the use of the mind. Thinking critically, analytically, and evaluatively means using mental processes such as attention, categorization, selection, and judgment [4]. 
Critical thinking is important because it plays a role in developing the various possible answers needed in the workplace to solve increasingly complex problems. [5-7]. The ability to think critically plays an important role in making the right decision based on facts and strong reasons, which are needed in work and everyday life $[8,9]$.

Critical thinking is a skill that is needed because it plays a role in developing the various possible answers needed in the world of work to solve increasingly complex problems. [5-7]. The ability to think critically plays an important role in making the right decision based on facts and strong reasons which are needed in the world of work and everyday life $[8,9]$.

There are several benefits of critical thinking: 1) improve the ability to observe; 2 ) focus more when reading; 3) improve the ability to identify important points in the text; 4) knowhow to acquire knowledge; 5) analytical skills can be applied to different situations [4]. However, these skills are not necessarily possessed by students. They must be taught in a disciplined manner in order to develop towards the tertiary level [3].

A result of a survey on critical thinking skills conducted by the Programme for International Student Assessment (PISA) on Indonesian students shows that students' critical thinking skills are still at a low level. Indonesia is ranked 72 out of 78 countries [10]. Several research results also reveal the same fact. The results of the study conducted by Prihatiningsih, Zubaidah, and Kusairi show that the critical thinking skills of junior high school students are low and underdeveloped [11], not much different from the results of a study conducted by Nuryanti, Zubaidah, and Diantoro that students' critical thinking skills are still poor with the percentage of students answering questions in the correct category only $40.46 \%$ [12].

Good critical thinking skills in a learning environment can have good implications for students in terms of fostering self-confidence, which can benefit from being an active contributor to the learning process [13-15]. Besides, critical thinking can also improve a person's ability to skillfully analyze, assess, and reconstruct what he/she thinks in solving problems [16]. It also increases student motivation in learning [17] and fosters students' scientific attitudes [18] as well as science process skills [19].

There is certainly a reason for the low ability of students to solve problems that require critical thinking. Several causes include that learning does not accommodate the growth of critical thinking due to the content learning system that emphasizes the memorization system and the unavailability of teaching materials that focus on developing critical thinking skills [20]. The learning system has so far emphasized the delivery of information compared to the development of students' thinking skills [21].

One way to develop critical thinking skills is by integrating them into teaching materials [22]. Teaching materials are one of the solutions to overcome the low level of critical thinking skills of students [20]. Teaching materials are a collection of knowledge, skills, and attitudes that students must learn to achieve the learning objectives that have been formulated [23]. Teaching materials play a role in facilitating students to learn, maintain interest, construct meaning in their logical structures independently of knowledge, and improve their thinking processes from lower to higher levels [24]. Therefore, teaching materials are needed to guide the thinking process of students from simple to more complex using a scientific approach.

A scientific approach is a learning approach applied in the 2013 curriculum [25]. The scientific approach to learning has five learning components: 1) observing; 2) asking questions; 3) trying/ gathering information; 4) reasoning/ associating, and 5) communicating [26].

Science teaching materials based on a scientific approach apply a scientific approach in the structure of writing and learning steps. In these materials, experimental activities are conducted aimed at explaining science as a process, a product of knowledge, the development of scientific attitudes, and the application of science in life. Active learning with experimental activities in the laboratory is one component that is integrated into teaching materials, which aims to activate students' thinking skills [27-29]. The application of scientific-based teaching materials seeks to activate students in the learning process to trigger critical thinking development [30].

\section{Methodology of Research}

\subsection{Research Method}

This study is development research. The development design used in this study adopted the Dick and Carey model, which was modified into four stages [31]. The development process consists of 1) Needs analysis; at this stage, an initial analysis was carried out to assess the product development goals. The purpose of product development is seen from two things, namely the teacher's need for teaching materials that apply the scientific approach and the development of students' critical thinking; 2) The design of teaching materials included the formulation of learning objectives, writing teaching materials following the scientific approach, deepening the content of the material, and evaluating; 3) The initial product evaluation stage was carried out to assess the feasibility of teaching materials from three aspects: content suitability, language suitability, and presentation, assessed by material expert lecturers; and 4) Application of teaching materials.

\subsection{Subject and Object of Research}

The subjects in this study were 45 students of grade 7 of Integrated Islamic School in Medan City, Indonesia. 
While the object in this study was students' critical thinking through the application of teaching materials based on a scientific approach.

\subsection{Instruments and Procedure}

The instruments used in the development of teaching materials in this study included (1) A checklist sheet, used for needs analysis; (2) the observation sheet for the implementation of scientific learning. It was used to assess the level of student participation in learning using scientific-based teaching materials; (3) the teaching material validation sheet; used for the assessment of the feasibility of teaching materials based on three criteria content feasibility, language eligibility, and presentation; (4) The response questionnaire; used to assess the level of student responses to the teaching materials used, and (5) The test of critical thinking skills in the form of an objective test of 10 points which was used to assess the level of students' critical thinking. The research applied the Research and Development (R\&D) procedure to study various findings in the field related to the product to be developed.

\subsection{Data Analysis Techniques}

The data analysis technique used in this research was descriptive and inferential statistics, where the data at the needs analysis stage, the design of teaching materials, and the initial assessment of the teaching material products developed were analyzed using descriptive statistics, while the data at the application stage were analyzed using descriptive and inferential statistics. The inferential analysis aimed to determine the effect of the use of teaching materials on students' critical thinking by using the independent sample t-test. Product testing was done using an experiment to compare classes that applied teaching materials and those that did not [32].

\section{Result and Discussion}

\subsection{Description of Need Analysis Results}

Science learning requires student involvement in learning through experiments to build scientific explanations of scientific phenomena in everyday life [33].
The achievement of science learning objectives needs to be supported by the ability of teachers to deliver subject matter and deepen the content of science teaching materials. The use of teaching materials that support the achievement of learning outcomes at K-13 needs to be done to develop the ability to understand and build scientific explanations on the structure of cognition, and students must interact with scientific phenomena through the teaching materials used. [34].

In a preliminary study conducted from three books used by the three schools that became the object of the research, the results of conformity with scientific steps were in the low category [35]. The results of the assessment of teaching materials using scientific steps on the three types of books available at school obtained a score of 53 with a low category for book A, book B scored 58, and book C scored 55 in the low category. Assessment refers to indicators of the scientific approach, namely observing, asking, trying, associating, and communicating. According to Rezba [36], the teaching materials used by students should meet the demands of the curriculum rather than just reading materials.

Teaching materials are one of the important components in learning that can help students understand subject matter independently. Every student has a different learning pace and understanding that affects their learning outcomes. Students are expected to progress according to their potential intelligence. Students must become the center of learning so that cognitive, character, and psychomotor develop optimally. Teaching materials are an effort to overcome this gap, and students must have a strong desire to read the available teaching materials.

\subsection{Description of Teaching Material Design}

The scientific approach is the basic concept that underlies the writing of teaching materials and their use in classroom learning, as stated in the lesson plan. The application of the scientific approach in learning using scientific-based teaching materials aims to develop the competence of students in carrying out scientific activities such as observing, asking questions, triggering curiosity, training students' literacy skills, training analytical skills, conducting experiments, communicating, and discussing to bring out students' creativity and critical thinking skills. Table 1 describes the scientific steps in teaching materials. 
Table 1. Description of scientific steps in the development of teaching material

\begin{tabular}{|c|c|}
\hline Scientific Steps & Learning Activity \\
\hline Observing & $\begin{array}{l}\text { Make observations of surrounding objects. Look at the objects shown such as: water, ice, salt, sugar, butter, milk, edible } \\
\text { oil, wood, coins, glass and others. }\end{array}$ \\
\hline Enquiring & $\begin{array}{c}\text { There are questions to ask students to think critically and diagnose knowledge and arouse curiosity and develop } \\
\text { thinking skills, namely: } \\
\text { Of these objects can anyone classify these objects according to their form. } \\
\text { Then how do we know the existence of objects that cannot be seen directly by the eye? } \\
\text { Can anyone explain whether these objects can undergo changes. }\end{array}$ \\
\hline Trying & $\begin{array}{l}\text { Practical activities are carried out for the following experimental purposes: } \\
\text { Students can group objects based on the state of the material: solid, liquid, and gas. } \\
\text { Students can explain the different states of matter based on solid, liquid, and gas. } \\
\text { Students can distinguish homogeneous and heterogeneous mixtures. } \\
\text { Students can distinguish between chemical changes and physical changes. } \\
\text { Students can do mixture separation }\end{array}$ \\
\hline Associating & $\begin{array}{l}\text { The questions to be analyzed are related to the experiment. Examples of experimental activities above try to answer the } \\
\text { following questions: } \\
\text { Can the mass and volume of the three types of matter be measured? Try to explain how to measure the mass and volume } \\
\text { of solids, liquids and gases! } \\
\text { Which of the three objects can be touched or held and which can only be smelled or tasted. Why are there differences in } \\
\text { properties between the three types of matter? }\end{array}$ \\
\hline Communicating & Activities to communicate the results of the experiment \\
\hline
\end{tabular}

To foster and improve students' critical thinking skills, the teaching materials developed were presented with aspects of observation and activities, as shown in Figure 1 below

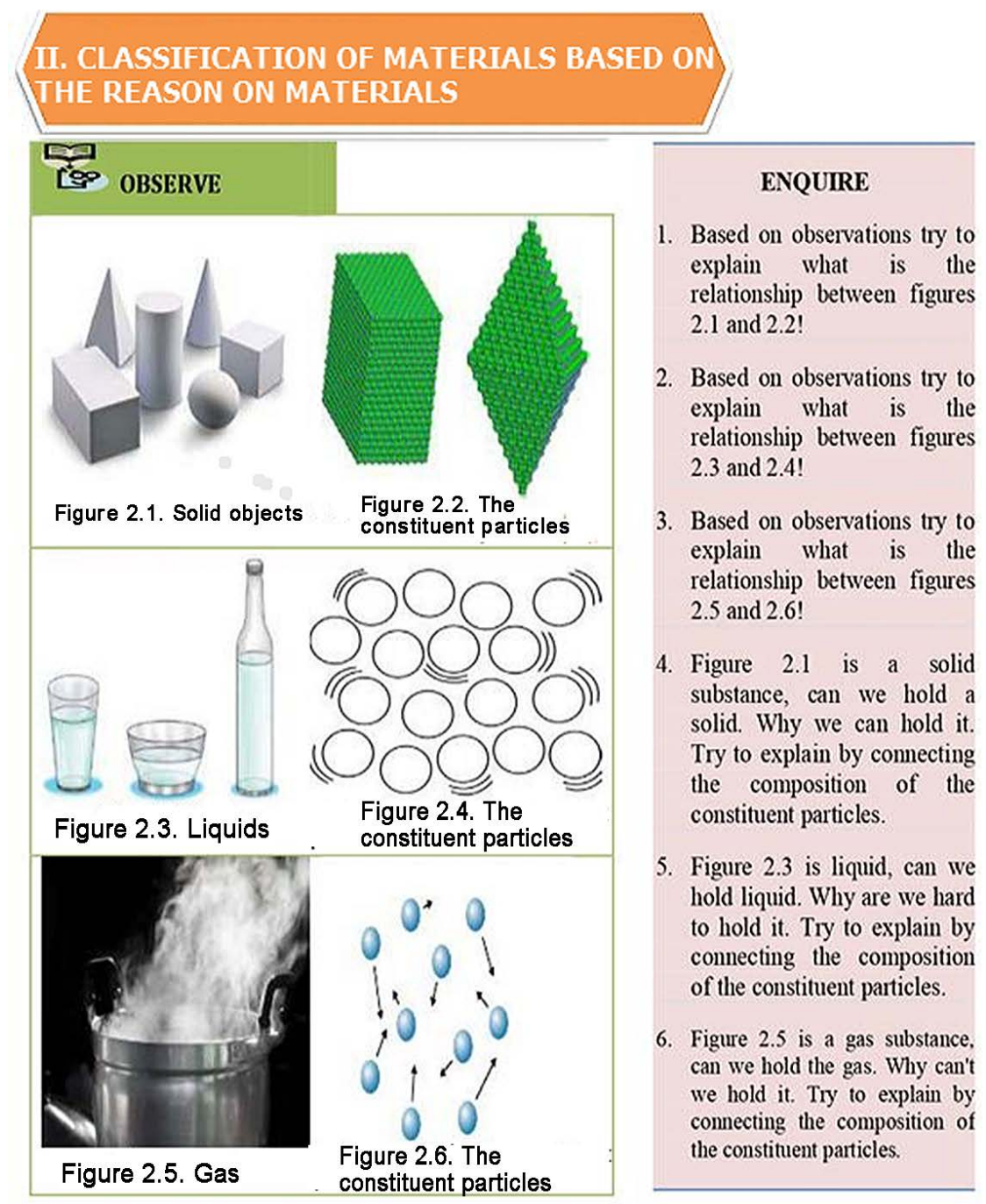

Figure 1. Illustration of Critical Thinking Activities on the Developed Teaching Materials 
Based on Figure 1, it can be seen that the teaching materials developed require students to be critical and active in constructing the concept of the material being taught. Because students must understand what is meant by a picture, Students make image observations on teaching materials, and after that, students can answer questions. Furthermore, teaching materials that have been compiled based on a scientific approach were analyzed by material experts. The following is a summary of the material expert's assessment of the teaching materials developed.

\subsection{Description of Initial Product Evaluation Results}

Scientific-based teaching materials that have been developed were assessed by material experts based on three eligibility categories. This assessment was carried out to assess whether the teaching material is suitable for use by teachers and students in the classroom. Based on the results of the expert evaluation of the feasibility of teaching materials in terms of the feasibility of the content, the feasibility of the language, and the feasibility of the appearance presented in Table 2, an average score of 4.28 was obtained (very good category).
This shows that teaching materials based on a scientific approach were suitable for use in the classroom [37]. After an assessment by a material expert was made, the teaching materials were used in learning as a guide for students, which consisted of observing, asking, trying, associating, and communicating components.

\subsection{Description of Results of Teaching Material Application}

At the stage of implementing teaching materials, the level of student participation in learning using teaching materials was observed and assessed. The results of student learning observations using teaching materials based on a scientific approach are presented in table 3 below.

Based on observations on the application of teaching materials in the learning process, it can be concluded that the teaching materials developed were feasible and can be used in the learning process as well as to be the learning guides for students. To determine the level of readability and student interest in teaching materials, an assessment was carried out by giving students a questionnaire after using the teaching materials.

Table 2. Expert assessment of material on developed teaching materials

\begin{tabular}{|c|c|c|c|c|}
\hline Validators & $\begin{array}{c}\text { Content eligibility (material } \\
\text { content) }\end{array}$ & Language Feasibility & Presentation Feasibility & Average \\
\hline V-1 & 4.63 & 4.47 & 4.36 & 4.49 \\
\hline V-2 & 4.53 & 4.2 & 4.29 & 4.34 \\
\hline V-3 & 4.32 & 4.27 & 4.21 & 4.27 \\
\hline V-4 & 4.16 & 4.13 & 4.21 & 4.17 \\
\hline V-5 & 4.11 & 4.27 & 4.07 & 4.15 \\
\hline
\end{tabular}

Table 3. The results of observations about students' participation in learning

\begin{tabular}{|c|c|c|c|}
\hline \multirow{2}{*}{$\begin{array}{c}\text { Scientific Approach } \\
\text { steps }\end{array}$} & \multicolumn{2}{|c|}{ The level of participation } & \multirow{2}{*}{ Explanation } \\
\hline & Percentage & Category & \\
\hline Observing & $63 \%$ & High & $\begin{array}{l}\text { Students found a relationship between the object being observed and the } \\
\text { learning materials }\end{array}$ \\
\hline Enquiring & $63 \%$ & High & $\begin{array}{l}\text { The ability to ask of junior high school students was still poor, so teachers } \\
\text { needed to make preliminary questions to trigger students' thought processes. }\end{array}$ \\
\hline Trying & $75 \%$ & High & $\begin{array}{l}\text { Students were interested in learning to use experiments to prove the facts and } \\
\text { theories contained in the learning material. }\end{array}$ \\
\hline Associating & $75 \%$ & High & $\begin{array}{l}\text { Grade I junior high school students found it difficult to reason because they are } \\
\text { used to getting information directly from their teachers. }\end{array}$ \\
\hline Communicating & $63 \%$ & High & $\begin{array}{l}\text { Students were still not used to communicating ideas from the results of their } \\
\text { thoughts. }\end{array}$ \\
\hline
\end{tabular}


The following are the results of the student response questionnaire to the teaching materials developed. Based on the questionnaire data on student responses to the teaching materials presented in Figure 2, it can be concluded that the student responses to teaching materials based on the scientific approach were in the high response category. However, in the first question about the students' obligation to read the teaching materials first was in the lowest rank with a score of 2.3. The first question was an important thing that students do to maximize the implementation of learning using the developed teaching materials.

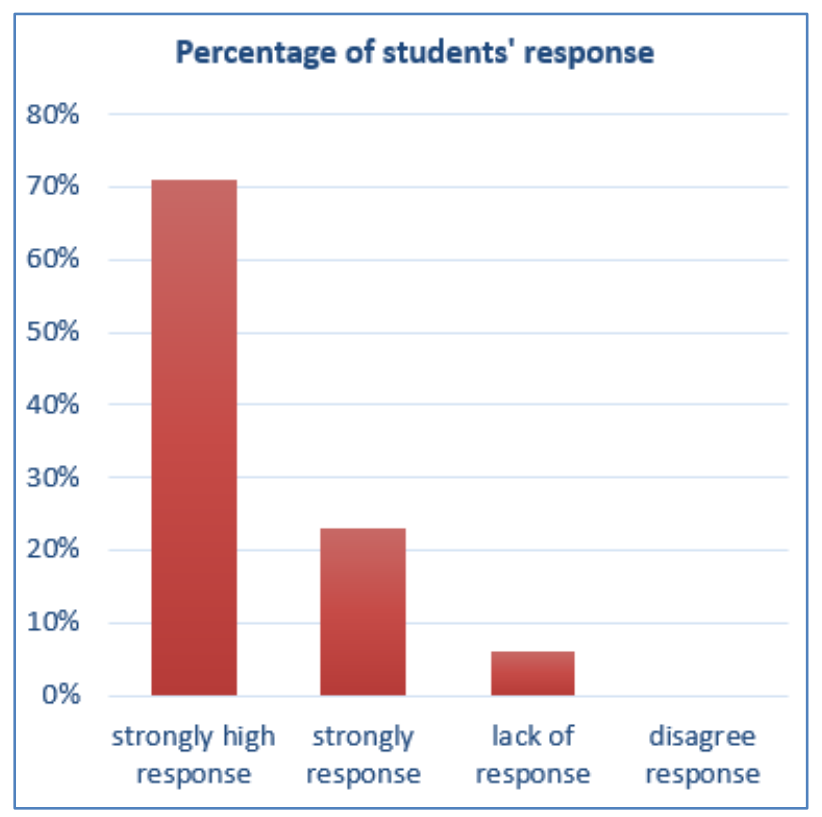

Figure 2. Students' responses to developed teaching material

Science teaching materials that have been developed were tried out in class to determine their effect on the development of students' critical thinking skills. Testing was conducted using the experimental class and the control class. Its effectiveness was analyzed using the Independent sample t-test, which is presented in Table 4, and the P-value obtained was 0.0437 , which is smaller than 0.05 , which means that teaching materials had an effect on increasing student grades and critical thinking skills.

Table 4. The results of independent sample t-test

\begin{tabular}{|l|c|c|c|}
\hline & Mean & Std. Deviation & P-value \\
\hline Group 1 & 59.59 & 25.96 & \multirow{2}{*}{0.0437} \\
\hline Group 2 & 52.65 & 15.67 & \\
\hline
\end{tabular}

Critical thinking skills were taught explicitly through learning in the classroom, assisted by teaching materials. One of the critical thinking skills is drawing conclusions. This thinking ability was taught through the following steps: (a) identifying questions or focusing on the conclusions made, (b) identifying known facts, (c) identifying previously known relevant knowledge, and (d) making predictions of the outcome. These steps are similar to the scientific approach to learning. This is one of the reasons for developing teaching materials based on a scientific approach [38].

Previous research on module development based on integrated scientific approach indicators of critical thinking has succeeded in improving cognitive learning outcomes for seventh-grade students of junior high school [39]. In the study of developing scientific-based teaching materials, the effect was seen in the development of critical thinking skills of 7th graders, who on average were 12-13 years old. At this age, students can develop logical thinking [40].

The scientific approach is closely related to the scientific method. Scientific teaching materials are teaching materials that adopt the flow of scientific thinking in writing and their implementation in learning. The learning process includes observing, asking, trying, associating (processing data), and communicating. Observing and asking questions can be done by students outside the classroom or while at home. Observation activities can be in the form of literature reviews and have been facilitated by the teacher through teaching materials. The activity of observing is an activity that takes a long time and requires students' care and independence for this activity. So that when students do not carry out these activities optimally at home, scientific activities such as trying, discussing, processing data, and communicating are not optimal [26]. In class, students must be more active in asking questions, trying, discussing with teachers and classmates, and communicating their findings.

To support the successful use of science teaching materials, teachers who guide and become facilitators of science teaching materials must have a strong literacy culture to construct meaning using the language for science learning, which is called linguistic skills [41]. Because in learning using a scientific approach, the teacher must be able to provoke questions and responses from students by using questioning and investigation skills to see to what extent students understand the explanations. Students are expected to understand the meaning of scientific terms. The poor ability of teachers to explain scientific terms can reduce students' motivation to learn science [42]. Improving scientific language skills will help develop understanding and improve students' ability to observe, think logically, and communicate effectively.

In addition, students must have the independence to read and study teaching materials so that other scientific activities can be carried out optimally in the classroom. The use of a scientific approach in learning requires a long time allocation, and so that the content of the material can be conveyed more deeply [43].

Critical thinking familiarizes students to think systematically, logically, directed, and can find solutions 
to the problems at hand. Developing critical thinking skills requires an independent training process that requires discipline, time, and effort [44,45]. Therefore independence in directing thinking activities is an important component in the development of critical thinking because, in its absence, critical thinking will not succeed [46].

\section{Conclusions}

Based on the results of this study, it was concluded that the teaching materials based on the scientific approach developed to improve students' critical thinking skills had met the feasibility, either in content, language, and appearance with a score of 4.28 in the very good category. Student responses to teaching materials based on a scientific approach were in the high response category. Besides, teaching materials based on scientific approaches are effective for improving students' critical thinking skills. This is obtained from the test results with the independent sample t-test, where the P-value was $0.0437<0.05$. This shows that teaching materials based on a scientific approach had an effect on increasing students' critical thinking skills. The development of scientific-based teaching materials aims to support the achievement of K-13 learning, which is to develop the ability to understand and build scientific explanations in the cognitive structure where students interact with scientific phenomena using guidelines from teaching materials. The application of the scientific approach in learning using scientific teaching materials aims to develop the competence of students in carrying out scientific activities, such as observing, asking questions, conducting experiments, and discussing to bring up the creativity and critical thinking skills of students. Learning science by using teaching materials that have been developed can help students in fostering their critical thinking skills, which is shown by increasing their learning activities and having a strong desire to follow scientific step by step in the learning process.

\section{REFERENCES}

[1] Santos, L.F. The Role of Critical in Scince Education. Journal of Education Practise. Vol 8, No.20, 159-173. 2017

[2] Saavedra, A. R., \& Opfer, V. D. Learning 21st Century skills requires 21 st Century Teaching. Phi Delta Kappan, Vol.94, No.2, 8-13. 2012

[3] Ennis, R. H. Critical Thinking Across the Curricu-lum: A Vision. Springer Science Business Media Dordrecht. 2016.

[4] Cottrell, S. Critical Thinking Skills: Effective Analysis, Argument and Reflection. Macmillan Publisher. 2017.

[5] Duran, M., \& Sendag, S. A Preliminary Investigation into
Critical Thinking Skills of Urban High School Students: Role of an IT/STEM Program. Creative Education. Vol.3, No.2, 241-250. 2012.

[6] Stephenson, N.S., \& McKningt N.P.S. Developing Critical Thinking Skills Using Science Writing Heuristic in The Chemistry Laboratory. Chemistry Education Research and Practise, Vol.17, 72-79. 2015.

[7] Quattrucci, J.G. Problem-Based Approach to Teaching Advanced Chemistry Laboratories and Developing Students' Critical Thinking Skills. Journal of Chemical Education. 2017.

[8] Bassham, G., Irwin, W., Nardone, H., \& Wallace, J. M. Critical thinking: A student's introduction (4th ed.). New York, NY: McGraw.2011.

[9] Vong, S.A. \& Kaewurai, W. Instructional Model Development to Enhance Critical Thinking and Critical Thinking Teaching Ability of Trainee Students at Regional Teaching Training Center in Takeo Province, Cambodia. Kasetsart Journal of Social Sciences. Vol. 38, 88-95. 2017

[10] Rini, D.S., Adisyahputra, \& Sigit, D.V. Boosting Student Critical Thinking Ability through Project Based Learning, Motivation and Visual, Auditory, Kinesthetic Learning Style: A study on Ecosystem Topic. Universal Journal of Education Research. Vol. 8, No.4A, 37-44. 2020

[11] Prihartiningsih., Zubaidah, S., \& Kusairi. Kemampuan Berpikir Kritis Siswa SMP pada Materi Klasifikasi Makhluk Hidup. Prosiding Seminar Nasional Pendidikan IPA Pascasarjana UM, Vol.1, 1053-1062. 2016.

[12] Nuryanti, L., Zubaidah, S., \& Diantoro, M. Analisis kemampuan berpikir kritis siswa SMP. Jurnal Pendidikan: Teori, Penelitian, dan Pengembangan, Vol.3, No.2, 155-158. 2018.

[13] Ristanto, R. H., Djamahar, R., Heryanti, E., \& Ichsan, I. Z. Enhancing Students' Biology-Critical Thinking Skill through CIRC-Based Scientific Approach (Cirsa). Universal Journal of Educational Research, Vol.8, No.4A, 1-8. DOI: 10.13189/ujer.2020.081801. 2018.

[14] Tsui, L. Effects of campus culture on students' critical thinking. The Review of Higher Education, Vol.23, No.4, 421-441. https://doi.org/10.1353/rhe.2000.0020. 2000.

[15] Miharja, F. J., Hindun, I., \& Fauzi, A. Critical thinking, metacognitive skills, and cognitive learning outcomes: A correlation study in genetic. Biosfer: Jurnal Pendidikan Biologi, 12(2), 135-143. https://doi.org/10.21009/biosferjp b.v12n2.135-143. 2019.

[16] Scriven, M., \& Paul, R. Defining critical thinking, foundation for critical thinking. Presented at the 8th Annual International Conference on Critical Thinking and Education Reform. 1987.

[17] Cholisoh, L., Fatimah, S., \& Yuniasih, F. Kemampuan berpikir kritis pada pembelajaran IPA terpadu ditinjau dari motivasi belajar. Jurnal Pendidikan IPA Indonesia, Vol.11, No.2, 134-141. 2015.

[18] Soh, T.M., Arsad, M.N., \& Osman, K. The relationship of 21st century skills on students' attitude and perception towards physics. Procedia Social and Behavioral Sciences, Vol.7, 546-554. 2010. 
[19] Nugraha, A.J, Suyitno, H., \& Susilaningsih, E. Analisis kemampuan berpikir kritis ditinjau dari keterampilan proses sains dan motivasi belajar melalui model PBL. Journal of Primary Education, Vol.6, No.1, 35-43. 2017.

[20] Setyowati, N., Sari, M.M.k, \& Habibah, S.M. Improving Critical Thinking Skills through the Development of Teaching Materials. Advances in Social Science, Education and Humanities Research. 1st International Conference on Social Sciences (ICSS). Vol 226. 240-245. 2018

[21] Zubaidah, S. Berpikir Kritis: Kemampuan Berpikir Tingkat Tinggi yang Dapat Dikembangkan melalui Pembelajaran Sains Makalah pada Seminar Nasional Sains 2010.

[22] Udi, E.A, \& Amit, M. Developing the skills of critical and creative thinking by probability teaching. Procedia - Social and Behavioral Sciences, Vol.15, 1087-1091. 2011

[23] Knoef, M.J. Attending to the Knowledge, Skills, and Attitudes of Teachers. University of Twente. https://essay.utwente.nl/72976/1/Knoef_MA_BMS.pdf. 2017.

[24] Fry, H., Ketteridge, S., Marshall, S. A Handbook for Teaching and Learning in Higher Education. Routledge: New York. 2009.

[25] Nugraha, I.S, \& Suherdi, D. Journal of English and Education. Vol. 5, No. 2. 112-119. 2017.

[26] Sani, R.A. Pembelajaran saintifik untuk implementasi kurikulum 2013 (Scientific learning for the implementation of the 2013 curriculum). Jakarta: Bumi Aksara. 2014.

[27] Stone, E.M. Guiding Students to Develop an Understanding of Scientific Inquiry: A Science Skills Approach to Instruction and Assessment. CBE-Life Sciences Education. Vol.13, 90-101. 2014

[28] Setiawan, D.\& Wilujeng, I. The development of scientific-approach-based learning instruments integrated with red onion farming potency in Brebes Indonesia. Jurnal Pendidikan IPA Indonesia, Vol.5, No.1, 22-30. 2016.

[29] Wardani, Y.R., Mundilarto, Jumadi, Wilujeng, I., Kuswanto, H., \&Astuti, D.P. The Influence of Practicum-Based Outdoor Inquiry Model on Science Process Skills in Learning Physics. Jurnal Ilmiah Pendidikan Fisika Al Biruni, Vol.8, No.1, 23-33. 2019.

[30] Kim K., Sharma P., Land S.M. and Furlong K.P. Effects of active learning on enhancing student critical thinking in an undergraduate general science course, Innov. High. Educ, Vol.38, 223-235. 2013

[31] Sugiyono. Metode penelitian dan pengembangan (Research and development methods). Bandung: Alfabeta. 2016.

[32] Mat Roni, S., Merga, M.K., \& Morris, J.E. Conducting quatitative research in education. Singapore: Springer Nature Singapore Pte Ltd. 2020.
[33] McNeill, K.L., \& Krajcik, J. Synergy between teacher practices and curricular scaffolds to support students in using domain-specific and domain-general knowledge in writing arguments to explain phenomena. Journal of the Learning Sciences, Vol.18, No.3, 416-460. 2009.

[34] Valentzas, A. \& Halkia. Scientific explanation in Greek upper secondary physics textbooks. International Journal of Science Education.1-17. 2017.

[35] Pohan, L.A., Maulina, J., Hasanah, U., \& Hardianti, T. Scientific approach in islamic junior high school science textbooks to facilitate high order thinking skills. International Journal of Engineering \& Technology, Vol.7, No.4.7, 442-444. 2018.

[36] Rezba, R.J., Sprague, C.R., McDonnough, J.T., \& Mat, J.J. Learning and assessing science process skills.Dubuque: Kendall/ Hunt Publishing Company. 2007.

[37] Kumar, S. Teaching Materials and Teaching Aids-I.Reasearch Gate. 2017.

[38] Rosnawati, R. Berpikir Kritis Melalui Pembelajaran Matematika untuk Mendukung Pembentukan Karakter Siswa. Seminar Nasional Pendidikan di Universitas Sanata Dharma. 2012.

[39] Dewi, I. S., Sunarno, W., \& Dwiastuti, S. Natural Sciences Module Based on Scientiific Approaches to Improve Cognitive Accomplishment of $7^{\text {th }}$. Jurnal Pendidikan Sains. Vol.5, No.3, 102-107. 2017.

[40] Samatowa, U. Pembelajaran IPA di Sekolah Dasar. Jakarta: Indeks. 2010.

[41] Taber, K.S. Exploring the language(s) of chemistry education, Chem. Educ. Res. Pract, Vol.16, 193-197. 2015.

[42] Markic, S., \& Childs, P.E. Language and teaching and learning of chemistry, Chem. Educ. Res. Pract, Vol.17, 434-438. 2016.

[43] Budiyanto, M.A.K., Waluyo, L., \& Mokhtar, A Implementasi pendekatan saintifik di pendidikan dasar Malang (Implementation of a scientific approach in basic education Malang). Proceeding Biology Education Conference, Vol.13, No.1, 46-51. 2016.

[44] Facione, P. Critical Thinking: What It Is and Why It Counts. (Online), (http://www.insightassessment.com). 2011.

[45] Toy, B.Y., \& Ok, A. Incorporating critical thinking in the pedagogical content of a teacher education programme: Does it make a difference? European Journal of Teacher Education, Vol.35, No.1, 39-56. doi:10.1080/02619768.20 11.634902. 2012

[46] Bleicher, E. The last class: Critical thinking, reflection, course effectiveness, and student engagement. Honors in Practice, Vol.7, 39-51. 2011. 